\title{
Identifying Big Data's Opportunities, Challenges, and Implications in Finance
}

\author{
Huidong Sun ${ }^{1}$, Mustafa Raza Rabbani ${ }^{2}$, Muhammad Safdar Sial ${ }^{3}$, Siming Yu ${ }^{4, *}$, \\ José António Filipe ${ }^{5}\left[\right.$ and Jacob Cherian ${ }^{6}[\mathbb{C}$ \\ 1 Economics and Management School, Wuhan University, Wuhan 430072, China; 2015101050086@whu.edu.cn \\ 2 College of Business Administration, Department of Finance and Accounting, Kingdom University, \\ Riffa 40434, Bahrain; m.rabbani@ku.edu.bh \\ 3 Department of Management Sciences, COMSATS University Islamabad (CUI), Islamabad 44000, Pakistan; \\ safdar.sial786@gmail.com \\ 4 Business School, Hubei University, Wuhan 430062, China \\ 5 Department of Mathematics, ISTA-School of Technology and Architecture, Iscte-Instituto Universitário de \\ Lisboa, Information Sciences, Technologies and Architecture Research Center (ISTAR-IUL), \\ Business Research Unit-IUL (BRU-IUL), 1649-026 Lisbon, Portugal; jose.filipe@iscte-iul.pt \\ 6 College of Business, Abu Dhabi University, Abu Dhabi 59911, UAE; jacob.cherian@adu.ac.ae \\ * Correspondence: yusiming19890622@163.com
}

Received: 12 September 2020; Accepted: 6 October 2020; Published: 10 October 2020

check for updates

\begin{abstract}
One of the latest innovations in business and technology is the use of big data, as daily data are generated by billions of events. The big data issue is now considered in the accountants and finance professionals' field as one of the most important sources for the analysis of financial products and services. This study is very innovative, with our research aiming to identify the opportunities, challenges, and implications of big data in the finance area. It is our purpose to find competitive advantages in terms of the extent to which big data brings visible benefits, also pointing out the challenges that a company may face in this field, such as cases of customers' data security or customer satisfaction processes. The identification of this kind of dynamics allows us to draw conclusions on the advantages of big data based on these analyses and big data's deep impact on finance. In particular, big data is now commonly used by financial institutions and banks for analytical purposes in financial market contexts. We conducted an exploratory survey of the existing literature to highlight such connections. In the last part of our study, we also propose directions for future research.
\end{abstract}

Keywords: big data; finance; opportunities; challenges; financial services; economic models

\section{Introduction}

Big data is one of the latest innovations in business and technology. Whilst big data is very relevant in many research fields, it is particularly significant in the finance area. Recent innovations in this context require firms to hire finance professionals, especially accountants, who also possess information technology (IT) skills, particularly because modern business dynamics call for that. At the same time, finance professionals and accountants who have relevant knowledge on their field (once, only very skilled professionals) can take full advantage of that, by integrating big data into decision-making processes.

In our work, we provide new knowledge concerning the studied issue. By analyzing and obtaining new information, our contribution provides new evidence and material that add to the development of the finance area in companies and shows how big data analysis is responsible for an easier decision-making process. 
Billions of financial transactions occur daily. The finance field cannot ignore this environment, in which big data prevails. It is now considered by finance professionals to be one of the most important sources for the analysis of financial products and services, and is considered a great source for benefits but, at the same time, is also a source of many concerns.

Our research aims to identify the opportunities, challenges, and implications of big data in finance. The purpose is to identify the areas in which benefits brought about by big data can be materialized to achieve a competitive advantage. Along with these benefits, there are challenges that a company has to face. The prospects brought about by big data in the field of finance are accompanied by a set of challenges, such as those relating to the data security of customers and customer satisfaction processes, which need to be identified by the business to take full advantage of big data. Big data in the field of finance has some remarkable uses in areas such as the detection of fraud, default rates, personal and institutional credit ratings, and online payment services, for example.

In our study, we reinforce some important points, showing that big data techniques are a valuable addition to the finance area, in particular after preparing tools with specific analytical procedures combined with financial techniques and a critical judgement. The study fills a lagging field by combining different valuable big data techniques to generate interesting results and conclusions. Our article makes an important contribution to the literature, allowing a bridge to fill the gap that still exists between finance research and organizations' practice in the big data field. Additionally, it shows several interesting specificities that finance has when compared to many other research trends.

The advent of information technology has led to the expansion of financial operations, which now include online banking and payment services, investment products, insurance, and innovation in corporate banking and financial services. Nowadays, the banking sector increasingly relies upon upcoming technology for the provision of most of its services. It has also been integrated into the main decision-making processes, such as the analysis of risk at both corporate and individual levels, the monitoring of transactions, and even corporate reporting. The design of such information technology in financial services is governed by local laws and regulations [1].

Big data is considered an emerging concept in all business sectors. Finance and accounting big data (FABD) has emerged as one of the most promising innovations since the advent of IT. This FABD has prompted changes in conventional business models in the financial sector and has proved to be a great tool in terms of managing corporate governance and financial decision making. This transformation is so rapid that many researchers point out that financial institutions might not be able to keep up with it. The emerging gap between financial research and information sciences in terms of research can be filled by the use of conventional econometric models [2]. In this world of limitless possibilities, researchers and data scientists can develop financial models based on big data in a way that they can create sophisticated risk management models with the aid of visualization, can create indices based upon sentiment, and propose and apply data-based controls using machine learning tools, which are widely available. They usually base these models on the data available on social networking sites and other common sources of data.

The advent of big data is linked to an increasing number of electronic devices for personal and corporate use. These devices include internet modems, mobile phones, tracking devices, computers, and satellite imagery. These devices, via communication, generate large volumes of data on a daily basis. They do not only generate personal, but also corporate, data. Moreover, computers are becoming more sophisticated and powerful, so they can handle a large volume of data within a small period. One example is Amazon's web services, which handle millions of parcels based upon this system. Another aspect to consider in terms of this subject is the advancement of machine learning tools, such as neural networks and deep learning, which enable people to process large volumes of statistical tools. The last factor is the development of algorithms that make big data-based analyses possible. The main changes that are brought about by big data in the field of finance are the sources of funds through a mix of debt financing and assets-based day to day transactions [3]. 
The main issue in finance is the rate of innovation brought about by information technology. It includes online transactions, funds generation via crowdfunding, online trading using these platforms, the creation of cryptocurrencies, and mobile banking platforms. Transactions via these platforms generate thousands of gigabytes of transaction data. The main consideration here is the management of such large-scale data, as these data also contain personal and financial information and if not handled properly, may end up in the wrong hands and can be devastating for many industries and businesses. Analysts have started to use such data for financial decision making, by analyzing the data on consumers' spending patterns and their social behaviors, using different predictive techniques and models. By applying such models, many industrial workers can decide which products or services should be launched and which should be discontinued [4,5]. Decision making has increased the importance of big data, as the information is considered the lifeblood of the industry and is the main difference between the success and failure of enterprises.

Big data is also playing an important role in enhancing the understanding of financial market mechanisms for the general public [6]. A countless amount of data is processed by the financial market on a daily basis for short- and long-term decision making [7]. Big data has advanced the mechanisms for fraud detection, helped in reforms in taxation systems, helped in the investigation of dubious anti-social financial activities, increased the rate of automation, and advanced risk analysis. It has transformed financial services and related sectors as trading has become automated, investments can be made online, risk analysis can be easily performed and, most of all, default and risk analysis can be easily conducted [8]. Big data has also enabled companies to monitor customer satisfaction and has greatly improved customer services in the banking and financial sectors [4]. Razin [9] has indicated the five basic changes brought about by the adoption of big data and related technologies: The increase in transparency; the improvement in risk analysis; automated trading; the arability of large-scale consumer data; and the transformation of general financial culture. Big data has also improved the levels and accuracy of economic models, along with helping to improve general economic analysis $[10,11]$.

Our research allows us to observe the specific reality of bigger companies, which have begun to use big data techniques in finance, when compared to smaller companies, which use them much less frequently; the literature review itself shows that big data is not yet used enough in finance, mainly by smaller companies in this area.

This research is qualitative. We analyzed the existing literature, and collected the point of view of practitioners and other stakeholders on big data as far as finance is concerned. This study aimed to provide an in-depth understanding of the changes brought about by big data in the field of finance by providing a snapshot of the latest developments and their impact. The existing literature on the impact of big data in the financial sector is limited and only a few academics have analyzed its impact on financial services. Although few studies have been conducted, they relate to a specific area of financial services. The opportunities presented by big data in this field, along with the threats, have scarcely been noted by researchers. The main reason for this is that this is a new avenue in the financial services sector. Therefore, further research is needed to provide a basis for understanding these issues in finance. This research explores the avenues which have not been explored by researchers, investigating the influence of big data on financial services, which is the most important novelty of this study.

The target audience of this research can gain an in-depth understanding of opportunities and challenges posed by adopting and integrating big data into finance and a basic understanding of the concept of big data. The work will also provide a solid platform for people conducting or planning to research the topic by incorporating different financial perspectives. Considering this, our main objective was to study the existing research on big data in the area of finance, by conducting an in-depth analysis on the papers in this field. We selected articles for the researched area considering financial markets, internet finance, financial analytics, internet finance and risk management, financial growth, innovation management, and data mining. 
The research is organized into the following sections: Section 2 presents the literature review; Section 3 presents the methodology; Section 4 presents the results and discussion; and, finally, Section 5 presents the conclusion and the directions for future research.

\section{Literature Review}

This paper offers a systematic literature review on the use of big data in finance fields. The expression "big data" was initially used to depict datasets whose size is beyond the ability of traditional means. The "big data" issue was developed during the 1990s and boosted in the mid-2000s. The extent of the term 'big data', which has essentially been extended in the long term, alludes to the data itself, as well as to a lot of other aspects, including-although is not restricted to-social phenomena, diagnostic or capacity advances, cycles, and frameworks [12].

Big data is commonly portrayed by three significant qualities: Volume, variety, and velocity. The three v's indicate outrageous data volumes, information type variety, and various information velocities [13]. In terms of the data volume, for instance, Nielsen can produce around 300,000 columns of ongoing information every second from a live review and yield more than one billion records for each month to conduct large information investigations [14]. As far as information type variety in concerned, extensive investigations of both organized and unstructured information can assist organizations with producing experiences from different sources, including customer exchanges, stock observing, store-based videos, advertisement and buyer relations, sales management, deals involving the executives, and monetary information $[15,16]$. For data velocity, big data investigations can empower continuous access and data sharing nearby to public governments for improved dynamics [17].

Currently, big data assumes a significant importance in different areas, for example, in science, research, building, medication, remedial services, funding, business, and society itself [18]. As "the new oil", it is an unending wellspring of information for the financial and social world [19]. In 2017, the yearly worldwide income for the enormous information market reached $\$ 33.5$ billion and is expected to multiply in the following four years. Additional driving innovation organizations, for example, IBM, SAP, Prophet, Hewlett Packard, and Accenture, have stepped up and use enormous information applications, offering related administrations.

The expected estimation of big data has likewise generated solid help from governments all over the world. The US previously declared the big data research and development work initiative in 2012, distributing more than $\$ 200$ million to big data research ventures. Numerous nations have joined in with this kind of task in subsequent years. In a scholarly network, big data-related distributions from various territories have undergone sensational development [20]. Nevertheless, big data's ability and its logical capacities allow a basic commitment to be guaranteed in areas such as traffic management, coordination, human services, and education [21-23]. Big data gives business and research value; it additionally creates notable challenges $[24,25]$ in terms of systems administration, stockpiling, management, and even ethics [26].

The idea of big data in business comes from the literature, where several studies have been published by relevant academic journals. At present, most of the business areas are connected to big data. Big data has a critical effect on different dimensions of businesses, for example, in terms of human resources management, research, and development [27,28]; management processes [27,29-31]; business to business processes, advertising, and marketing [32,33]; mechanical assembling measures [34-36]; enterprises' operational performance [36,37]; policy-making [38]; and supply chain management [38,39]. In particular, Rabhi, Falih [27] referenced big data as a noteworthy factor of business measure management and HR cycles to help in the decision-making process. This investigation also discussed three complex sorts of examination methods (enlightening examination, prescient investigation, and prescriptive examination) to improve the customary information examination measure. Duan and Xiong [40], Jiang, Lee [41], and Pappas, Mikalef [42] investigated the noteworthiness of big data in business examination. Big data assists with tackling business issues 
and data management through a framework foundation, which incorporates strategies to catch, store, move, and process the information.

Business analytics and the business system must be firmly connected to increase better investigation-driven experiences. Grover and Kar [29] referenced firms that are similar to Apple, Facebook, Google, Amazon, and eBay, which routinely use digitized transactions to appraise the state of their market for improving their business tasks [43]. Holland, Thornton [32] indicated the hypothetical and exact commitments of big data in business. This investigation construed that business to business connections from buyers' search designs are used to assess and quantify the online presentation of rivals in the US carrier market. Furthermore, big data additionally helps to cultivate business to business deals with clients' information examination. The utilization of clients' enormous datasets essentially improves sales, growth, and the relationship with customers [44].

The discussion presented above is based on the various extents of business. Some studies [45-47] have focused on different areas of financial services, but the contributions to this issue have not yet been expanded upon enough. Our current study intends to enlarge big data's contribution to finance.

\section{Materials and Methods}

As previously stated, the main purpose of the current study was to identify the opportunities, challenges, and implications of big data in finance. To accomplish this task, we thoroughly analyzed the secondary data sources on this topic [4]. Figure 1 represents the systematic framework for our research structure. We used the most prominent databases of Scopus, Google Scholar, and Web of Science [4]. We searched for the following keywords: Big data; big data in finance; big data in accounting; big data in management; FinTech, and big data; and stock market, and big data. We mainly focused on high-quality peer-review journals for our research, but we did not ignore articles on the topic available on different websites. We also made use of common search engines to enhance our understanding of the topic. We did not impose time limitations on the academic material, as the research on the topic is already scant and such a limitation would have further reduced the academic literature to be used. Our research provides relevant information that can be structured in terms of papers by journal and database, including the number of academic papers published, taking into account the years of publication and the academic fields; the main countries in terms of the research; and the cited references, which have been considered by several recent studies [48-50].

\subsection{Papers by Journal and Database}

We gave priority to well -established and prominent publishers, such as Sage, Taylor and Francis, Elsevier, Emerald, and Wiley for data collection [4]. We only found 130 articles from all of these databases; the number was further reduced to 70 after scrutiny. Our data set only contained 70 articles that were directly related to the topic. The list of journal articles is provided in Table 1, in a summarized form. 


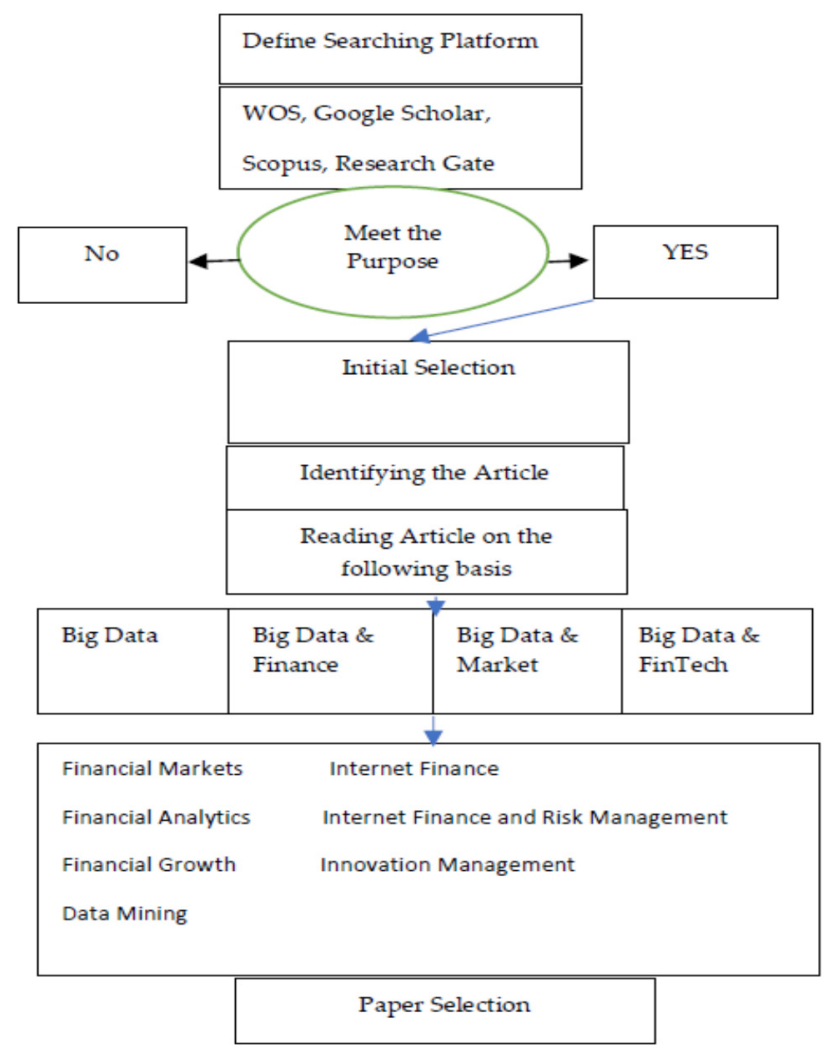

Figure 1. Systematic Framework for the Research Structure.

Table 1. List of published papers relating to big data in finance.

\begin{tabular}{lll}
\hline \multicolumn{1}{c}{ Journal Name } & $\begin{array}{c}\text { Number of Published } \\
\text { Articles (70) }\end{array}$ & \multicolumn{1}{c}{ Publisher's Name } \\
\hline Journal of Big Data & 2 & Springer \\
\hline Journal of Business Logistics & 1 & Willy \\
\hline $\begin{array}{l}\text { International Journal of Production } \\
\text { Economics }\end{array}$ & 1 & Elsevier \\
\hline International Business Review & 1 & Elsevier \\
\hline Mathematical Population Studies & 1 & Taylor \& Francis \\
\hline Journal of Econometrics & 1 & Elsevier \\
\hline Procedia Computer Science & 1 & Elsevier \\
\hline Australian Accounting Review & 1 & Willy \\
\hline Research-Technology Management & 1 & Taylor \& Francis \\
\hline $\begin{array}{l}\text { Global Journal of Flexible Systems } \\
\text { Management }\end{array}$ & 1 & Springer \\
\hline Journal of Intelligent \& Robotic Systems & 1 & Springer \\
\hline Industrial Marketing Management & 2 & Elsevier \\
\hline International Journal of Information & 1 & Elsevier \\
\hline Management & 1 & Elsevier \\
\hline Journal of cleaner production & 1 & Elsevier \\
\hline Computers \& Industrial Engineering & 2 & Elsevier \\
\hline Journal of Monetary Economics & &
\end{tabular}


Table 1. Cont.

\begin{tabular}{|c|c|c|}
\hline Journal Name & $\begin{array}{c}\text { Number of Published } \\
\text { Articles (70) }\end{array}$ & Publisher's Name \\
\hline Journal of the Operational Research Society & 1 & Taylor \& Francis \\
\hline Journal of Accounting Literature & 1 & Elsevier \\
\hline Journal of Monetary Economics & 1 & Elsevier \\
\hline Expert Systems with Applications & 1 & Elsevier \\
\hline Journal of the Operational Research Society & 1 & Taylor \& Francis \\
\hline $\begin{array}{l}\text { Computational Social Science and } \\
\text { Humanities }\end{array}$ & 1 & Springer \\
\hline Annals of Operations Research & 1 & Springer \\
\hline Management Decisions & 1 & Emerald \\
\hline Vietnam Journal of Computer Science & 1 & World scientific \\
\hline $\begin{array}{l}\text { Journal of parallel and distributed } \\
\text { computing }\end{array}$ & 1 & Elsevier \\
\hline $\begin{array}{l}\text { International Journal of Production } \\
\text { Economics }\end{array}$ & 1 & Elsevier \\
\hline Scientometrics & 1 & Springer \\
\hline Information systems & 1 & Willy \\
\hline Resources, Conservation and Recycling & 1 & Elsevier \\
\hline Journal of Management Analytics & 1 & Taylor \& Francis \\
\hline Advances in Accounting & 1 & Elsevier \\
\hline $\begin{array}{l}\text { Information Systems and e-Business } \\
\text { Management }\end{array}$ & 1 & Springer \\
\hline New Horizons for a Data-Driven Economy & 1 & Springer \\
\hline $\begin{array}{l}\text { International Journal of Electronic } \\
\text { Commerce }\end{array}$ & 1 & Taylor \& Francis \\
\hline Journal of Corporate Accounting \& Finance & 1 & Willy \\
\hline Emerging Markets Finance and Trade & 1 & Taylor \& Francis \\
\hline Financial Innovation & 1 & Springer \\
\hline Journal of Information Systems & 1 & Elsevier \\
\hline Information, communication \& society & 1 & Taylor \& Francis \\
\hline Strategy \& Leadership & 1 & Emerald \\
\hline Accounting Horizons & 2 & American Accounting Association \\
\hline International Journal of Auditing & 1 & Willy \\
\hline Journal of computational science & 1 & Elsevier \\
\hline China Economic Journal & 1 & Taylor \& Francis \\
\hline $\begin{array}{l}\text { International Journal of Accounting } \\
\text { Information Systems }\end{array}$ & 1 & Elsevier \\
\hline Decision support systems & 1 & Elsevier \\
\hline Journal of Business Research & 1 & Elsevier \\
\hline Others & 18 & \\
\hline
\end{tabular}




\subsection{Number of Articles Published by Year}

As we can see in Table 2, this topic's importance has developed in the literature, having significantly increased in the few last years. The largest number of publications was recorded for the years 2018 and 2019 ( $\mathrm{N}=13 ; 18.57 \%$ each year). For 2020, it is expected that the number will be higher, as many papers are not yet available online for this year. We can observe that for the years from 1990 until $2010(\mathrm{~N}=5$; $7.15 \%$ for the entire period), there are considerably small numbers recorded for the publications in this area. On this basis, it can be easily understood that this is a new topic. There is growing evidence on the awareness and importance of this area among the academic community, practitioners, and even governments worldwide.

Table 2. Total number of published articles, by year.

\begin{tabular}{lll}
\hline \multicolumn{1}{c}{ Year } & No. of Published Articles & Percentage \\
\hline 2020 & 6 & 8.57 \\
\hline 2019 & 13 & 18.57 \\
\hline 2018 & 13 & 18.57 \\
\hline 2017 & 4 & 5.71 \\
\hline 2016 & 4 & 5.71 \\
\hline 2015 & 8 & 11.43 \\
\hline 2014 & 7 & 10 \\
\hline 2013 & 5 & 7.14 \\
\hline 2012 & 3 & 4.29 \\
\hline 2011 & 2 & 2.86 \\
\hline $1990-2010$ & 5 & 7.15 \\
\hline Total & $\mathbf{7 0}$ & $\mathbf{1 0 0}$ \\
\hline & Source: Own elaboration.
\end{tabular}

\subsection{Number of Articles Published by Academic Field}

Table 3 gives the number of published papers on the basis of the academic field. By analyzing the literature, we found some major factors that can be related to the use of big data in finance. These factors have deeply impacted the world of finance and mainly include financial markets, internet banking, financial analytics, internet finance and risk management, financial growth, innovation management, and data mining.

Table 3. Total number of published articles on the basis of academic fields, by authorship.

\begin{tabular}{|c|c|c|c|c|c|c|c|}
\hline Major Studies & $\begin{array}{l}\text { Financial } \\
\text { Markets }\end{array}$ & $\begin{array}{l}\text { Internet } \\
\text { Banking }\end{array}$ & $\begin{array}{l}\text { Financial } \\
\text { Analytics }\end{array}$ & $\begin{array}{c}\text { Internet } \\
\text { Finance and } \\
\text { Risk } \\
\text { Management }\end{array}$ & $\begin{array}{l}\text { Financial } \\
\text { Growth }\end{array}$ & $\begin{array}{l}\text { Innovation } \\
\text { Management }\end{array}$ & $\begin{array}{c}\text { Data } \\
\text { Mining }\end{array}$ \\
\hline Andriosopoulos, D., et al. & & & $x$ & & & & \\
\hline Sun, Y., Shi, Y. and Zhang, Z & & & & & & & $x$ \\
\hline Routledge, B.R., & & & & & & & $X$ \\
\hline $\begin{array}{l}\text { Morshadul, H.M., József, P. } \\
\text { and Judit, O. }\end{array}$ & & & & & & & $x$ \\
\hline Hale, G. and Lopez, J.A. & & & & & & & $X$ \\
\hline Shen, D. and Chen S.-H. & $x$ & & & & & & \\
\hline Ewen, J. & & & & & & & $X$ \\
\hline Hill, C. & $x$ & & & & & & \\
\hline
\end{tabular}


Table 3. Cont.

\begin{tabular}{|c|c|c|c|c|c|c|c|}
\hline Major Studies & $\begin{array}{l}\text { Financial } \\
\text { Markets }\end{array}$ & $\begin{array}{l}\text { Internet } \\
\text { Banking }\end{array}$ & $\begin{array}{l}\text { Financial } \\
\text { Analytics }\end{array}$ & $\begin{array}{c}\text { Internet } \\
\text { Finance and } \\
\text { Risk } \\
\text { Management }\end{array}$ & $\begin{array}{l}\text { Financial } \\
\text { Growth }\end{array}$ & $\begin{array}{l}\text { Innovation } \\
\text { Management }\end{array}$ & $\begin{array}{l}\text { Data } \\
\text { Mining }\end{array}$ \\
\hline Razin, E. & & & & & & & $x$ \\
\hline Diebold, F.X., et al. & & $x$ & & & & & \\
\hline Einav, L. and Levin, J. & & & & & $x$ & & \\
\hline Mishra, D., et al. & & & & & & & $x$ \\
\hline Russom, P. & & & & & & & $x$ \\
\hline Prescott, M.E. & & & & & & & $x$ \\
\hline Stahl, F., et al. & & & & $x$ & & & \\
\hline Kambatla, K., et al. & & & $x$ & & & & \\
\hline Wamba, S.F., et al. & & & $x$ & & & & \\
\hline Dumbill, E. & & & & $x$ & & & \\
\hline $\begin{array}{l}\text { Hasan, S., Shamsuddin, S.M. } \\
\text { and Lopes, N. }\end{array}$ & & & & & & & $x$ \\
\hline Huang, Y., et al. & & & & & $x$ & & \\
\hline Hashem, I.A.T., et al. & & & & & & & $x$ \\
\hline $\begin{array}{l}\text { De Mauro, A., Greco, M. } \\
\text { and Grimaldi, M. }\end{array}$ & & & $X$ & & & & \\
\hline $\begin{array}{l}\text { Waller, M.A. and } \\
\text { Fawcett, S.E. }\end{array}$ & & & $x$ & & & & \\
\hline \multicolumn{8}{|l|}{ Marx, V., Biology } \\
\hline $\begin{array}{l}\text { Chen, H., Chiang, R.H. } \\
\text { and Storey, V.C. }\end{array}$ & & & $x$ & & & & \\
\hline Tole, A.A., & & & & & $x$ & & \\
\hline Rabhi, L., et al. & & & $x$ & & & & \\
\hline Blackburn, M., et al. & & & & & & $x$ & \\
\hline Grover, P. and Kar, A.K. & & $x$ & & & & & \\
\hline Ji, W., Yin, S. and Wang, L. & & & & & & & $x$ \\
\hline $\begin{array}{l}\text { Arunkumar, G., Sabnis, A. } \\
\text { and Vachhani, L. }\end{array}$ & & & & & & $x$ & \\
\hline $\begin{array}{l}\text { Holland, C.P., Thornton, S.C. } \\
\text { and Naudé, P. }\end{array}$ & & & $x$ & & & & \\
\hline Liu, Y., et al., & & & & & & $X$ & \\
\hline $\begin{array}{l}\text { Huang, L., Wu, C. } \\
\text { and Wang, B. }\end{array}$ & & & & & & $x$ & \\
\hline $\begin{array}{l}\text { Huang, L., Wu, C. } \\
\text { and Wang, B. }\end{array}$ & & & & & & $X$ & \\
\hline Belhadi, A., et al. & & & & & & $x$ & \\
\hline Dubey, R., et al. & & & & & & & $x$ \\
\hline Shamim, S., et al. & & & & & & $x$ & \\
\hline Aragona, B. and De Rosa, R. & & & & & & & $x$ \\
\hline Bag, S., et al. & & & $x$ & & & & \\
\hline Duan, L. and Xiong, Y. & & & $x$ & & & & \\
\hline $\begin{array}{l}\text { Jiang, W., Lee, P. and } \\
\text { Anandarajan, A. }\end{array}$ & & & & $X$ & & & \\
\hline Pappas, I.O., et al. & & & $x$ & & & & \\
\hline Thackeray, R., et al. & & & & & & $x$ & \\
\hline $\begin{array}{l}\text { Hallikainen, H., Savimäki, E. } \\
\text { and Laukkanen, T. }\end{array}$ & & & $x$ & & & & \\
\hline Cerchiello, P. and Giudici, P. & & & & $x$ & & & \\
\hline
\end{tabular}


Table 3. Cont

\begin{tabular}{|c|c|c|c|c|c|c|c|}
\hline Major Studies & $\begin{array}{l}\text { Financial } \\
\text { Markets }\end{array}$ & $\begin{array}{l}\text { Internet } \\
\text { Banking }\end{array}$ & $\begin{array}{l}\text { Financial } \\
\text { Analytics }\end{array}$ & $\begin{array}{c}\text { Internet } \\
\text { Finance and } \\
\text { Risk } \\
\text { Management }\end{array}$ & $\begin{array}{l}\text { Financial } \\
\text { Growth }\end{array}$ & $\begin{array}{l}\text { Innovation } \\
\text { Management }\end{array}$ & $\begin{array}{l}\text { Data } \\
\text { Mining }\end{array}$ \\
\hline \multicolumn{8}{|l|}{ Hussain, K. and Prieto, E. } \\
\hline Tang, Y., et al. & $X$ & & & & & & \\
\hline $\begin{array}{l}\text { Begenau, J., Farboodi, M. } \\
\text { and Veldkamp, L. }\end{array}$ & & & & & $X$ & & \\
\hline Fanning, K. and Grant, R. & $x$ & & & & & & \\
\hline Yang, D., et al. & & & & $X$ & & & \\
\hline Zhang, S., et al. & & & & & $X$ & & \\
\hline Richins, G., et al. & & & & & & $x$ & \\
\hline Boyd, D. and Crawford, K. & & & & & & $x$ & \\
\hline Davenport, T.H. & & & & $x$ & & & \\
\hline Hannan, S.A. & & & & & & & $x$ \\
\hline $\begin{array}{l}\text { Warren Jr, J.D., Moffitt, K.C. } \\
\text { and Byrnes, P. }\end{array}$ & & & & $x$ & $\mathrm{X}$ & & \\
\hline $\begin{array}{l}\text { Vasarhelyi, M.A., Kogan, A. } \\
\text { and Tuttle, B.M. }\end{array}$ & & & $x$ & & & & \\
\hline $\mathrm{Du}, \mathrm{H}$. and Roohani, S. & $x$ & & & & & & \\
\hline $\begin{array}{l}\text { Bollen, J., Mao, H. } \\
\text { and Zeng, X. }\end{array}$ & $X$ & & & & & & \\
\hline Butler, J.E. and Hansen, G.S. & & & & & & $x$ & \\
\hline Kh, R. & & & & & & $x$ & \\
\hline $\mathrm{Niu}, \mathrm{S}$. & & & & $X$ & & & \\
\hline Xie, P., Zou, C. and Liu, H. & & & & $x$ & & & \\
\hline $\begin{array}{l}\text { Gray, G.L. and } \\
\text { Debreceny, R.S. }\end{array}$ & & & & & $x$ & & \\
\hline Ngai, E.W., et al. & & & & & $x$ & & \\
\hline Jin, M., Wang, Y. and Zeng, Y. & & & & $X$ & & & \\
\hline Nassirtoussi, A.K., et al. & $x$ & & & & & & \\
\hline $\begin{array}{l}\text { Hajizadeh, E., Ardakani, H.D. } \\
\text { and Shahrabi, J. }\end{array}$ & $x$ & & & & & & \\
\hline $\begin{array}{l}\text { Pérez-Martín, A., } \\
\text { Pérez-Torregrosa, A. } \\
\text { and Vaca, M. }\end{array}$ & & $x$ & & & & & \\
\hline Cockcroft, S. and Russell, M. & & $x$ & & & & & \\
\hline Total & 8 & 4 & 13 & 10 & 8 & 12 & 15 \\
\hline
\end{tabular}

\subsection{Number of Researchers by Country}

Table 4 shows the number of researchers (180, including papers' co-authors) by country for the published papers on big data in finance and related fields (70), representing a total of 24 countries around the world from 1991 until 2020. It was considered suitable to include co-authors, in order to avoid misrepresentation by allowing the wrong idea that each paper had a single author. From the total number of articles analyzed (i.e., 70), the largest number of scholarly contributions are from the USA ( $\mathrm{N}=53$ scholars, representing $29.44 \%$ ), followed by China $(\mathrm{N}=34 ; 18.89 \%)$, and then the UK $(\mathrm{N}=17 ; 9.44 \%)$, Malaysia $(\mathrm{N}=12 ; 6.67 \%)$, and France $(\mathrm{N}=7 ; 4.68 \%)$. The results in Table 4 show that the USA and China lead the big data research on this area. This is significant considering that some countries are giving clear signals of great interest in the big data area. 
Table 4. Number of researchers by country.

\begin{tabular}{|c|c|c|}
\hline Country & No. of Researchers & Percentage \\
\hline Greece & 3 & 1.67 \\
\hline USA & 53 & 29.44 \\
\hline France & 7 & 3.89 \\
\hline UK & 17 & 9.44 \\
\hline China & 34 & 18.89 \\
\hline Poland & 2 & 1.11 \\
\hline Taiwan & 1 & 0.55 \\
\hline India & 6 & 3.33 \\
\hline Germany & 6 & 3.33 \\
\hline New Zealand & 1 & 0.55 \\
\hline South Africa & 3 & 1.67 \\
\hline Portugal & 1 & 0.55 \\
\hline Morocco & 5 & 2.78 \\
\hline Malaysia & 12 & 6.67 \\
\hline Australia & 5 & 2.78 \\
\hline Italy & 3 & 1.67 \\
\hline Romania & 1 & 0.55 \\
\hline Pakistan & 1 & 0.55 \\
\hline Turkey & 1 & 0.55 \\
\hline Norway & 3 & 1.67 \\
\hline Finland & 3 & 1.67 \\
\hline Canada & 5 & 1.67 \\
\hline Iran & 4 & 2.22 \\
\hline Spain & 3 & 1.67 \\
\hline Total & 180 & $100 \%$ \\
\hline
\end{tabular}

\subsection{Most Cited Articles}

Table 5 presents the top five cited publications with authors' names, year, and journal name with the number of citations.

Table 5. Top five most cited articles.

\begin{tabular}{clcc}
\hline Author Names & Year & Journal Name & Number of Citations \\
\hline Chen, H., Chiang, R.H. and Storey, V.C. & 2012 & MIS Quarterly & 5324 \\
\hline Bollen, J., Mao, H. and, Zeng, X. & 2011 & Journal of Computational Science & 4841 \\
\hline Boyd, D. and Crawford, K. & 2012 & Information, Communication \& Society & 3820 \\
\hline Hashem, I.A.T., et al. & 2015 & Information Systems & 2190 \\
\hline Waller, M.A. and Fawcett, S.E. & 2013 & Journal of Business Logistics & 1037 \\
\hline
\end{tabular}




\section{Results and Discussion}

The ever-evolving technology and big data are changing the basic operating structure of organizations. The world of finance is no exception. Big data has also had a deep impact on the finance sectors, as well as in other fields of social sciences [46,51-54]. Big data is playing a key role in the development of the financial sector, as in internet-based banking or other financial services, such as risk analysis, credit rating, the management of financial resources and products, and automated trading and clearing, which have greatly benefited from its use. Based on the literature, we classified the analysis into four areas: first, the implication of big data in finance; second, implications of big data in financial markets; third, the implication of big data in internet finance; fourth, the implication of big data in managerial financial services. The discussion of these four categories is one of our main contributions to the existing literature, with these areas being central to the use of big data in finance-related services. However, before the analysis of the implications of big data, it is important to discuss the opportunities and challenges of big data in finance.

\subsection{Opportunities of Big Data in Finance}

Big data plays a very central role in strengthening the affairs of a business. People's lives are improved by easing the way in which business is done. Accelerating processes can work as a major opportunity to increase big data's significance. The integration of the Internet of Things (IoT) can be seen as one of the latest involvements of big data. Sensors linked to things generating meaningful data and information which aid in decision-making processes are known as IoT. Interoperability is the concept that is combined to update, analyze, and access the data needed in an uncomplicated and swift manner. This concept caters to the user by allowing them to access the most diverse data without difficulty. A connection is established amongst people, devices, machines, and sensors, by considering the alliance involving the notion of the Internet of Things [55]. This merger happens through a network of interrelated devices and sensors that cause a signal to be sent to notify about any changes that may occur. All of the operations can be controlled through an individual data source by means of the application of this incorporation.

Through the means of sensors, all devices relate to one another. Analyzing the characteristics of the real world and then producing numerical or analytical information is one of the uses of IoT. Specifically, in the field of finance, this system is vital because the information processing system turns the data into useful information that helps in the process of making decisions. The merging of the concept of IoT with finance distinctly helps in the tracking of the inventory. It would also help in measuring the performance of the company in the past and forecasting the future purchases of the company.

Decentralization of the process of making decisions is one of the most salient opportunities to emerge with big data. The systems are now competent and have proven to be efficient in making decisions based on the information available to them and set standards, all with the help of big data. The judgment that the system makes is based on the provided situation and by observing past trends [55]. These operations take place without the involvement of a human, except for unusual cases that include a dispute. Big data solutions assist accountants in performing actions that need to be repeated regularly, without any lag. All the minor details do not need to be checked by the accountants themselves anymore.

The utilization of predictive analytics and data visualization is another major utility of big data in the field of finance [56]. The process of decision making is achieved from objective facts and figures when finance practices are dependent on the predictive analysis. Hence, the process of data analysis is simplified through this procedure. There used to be big chunks of data available before big data evolved and there were no procedures to process it properly to produce information that could be analyzed for decision making. With the help of many data visualization approaches, the decision-making process has been made easy for accountants and financial analysts. There are minimal lags in the exhibition of the data right after any big change when big data is employed, thus making the choices 
easier. Accountants and financial analysts have made it available to discover the stores of big data and efficiently correlate the chance of addressing the needs properly. Insights are available for every person and any place using these visualizations.

Since the field of finance needs a lot of data to be refined into information before it can be used, big data is very beneficial in this field. A lot of data needs to be managed by the accounts in every facet. Big data solutions are primarily based on data-driven results of audits, so they produce finer outcomes for both the client and auditor. Apart from that, in the advisory area, the big data recognizes the questions that assist in the improvement of business operations along with the monitoring of the performance. Analytical models assist in aiding the operational betterment and product variation [57]. It can be argued that big data can be used by accountants and financial analysts to manage and eliminate, if possible, the involved risk.

\subsection{Challenges of Big Data in Finance}

Data have been created at a very fast pace in the past few years. The amount of data that has been generated over the past decade has not been created for thousands of years of evolution of human civilizations. Data utilization is necessary and important for making important decisions. From all of the data created and collected, approximately only $0.5 \%$ is analyzed and utilized [58]. The rest of the data can also be turned into value-added information, being a very promising challenge. Even though these data can be passed to the company's tables and allow it to increase its revenues, there is a set of obstacles that are correlated with the utility of big data in the field of finance.

The expectations that are now linked with companies' Chief Financial Officers (CFOs), when considering their management, are related to the provision of insightful information that is based on the data created and collected. These expectations have given a very central and critical role to the finance departments. The conventional roles and practices have now evolved because of the great potential of the analysis. Therefore, this is only able to be considered when the prediction is embedded and practiced to have an impact on the performance. This is the only way to help with the understanding of customers and their behaviors, the trend prediction, better decisions for prices, risk management, looking for new business and profitability opportunities, and enhancing the supply chain. Investments in data analysis result in financial companies struggling and fighting to get positive returns. There are a couple of grounds that become the basis for negative returns, as mentioned below.

First, accountants face difficulties in inspecting and analyzing the correct data. Garbage data produce garbage outcomes; therefore, if debris data is being observed and processed, it is of no utility. The analytics have evolved from descriptive to diagnostic, to predictive, and now to perspective analysis, which is currently being used for identifying ideal solutions. However, these analytics can only produce ideal outcomes when the data being processed have been obtained from a reliable source. The accountant and financial analyst needs to make judgments on what kind of data is going to be used. If the data that are initially taken are flawed, then no matter how efficiently they are processed, the results will be false-leading [59]. Understanding the right type of data is required to overcome this problem and then is necessary to check if any extra data are required for the analysis.

Second, one of the major issues faced is having a vague data strategy. A sound and rational strategy is needed if the company is expecting to have high returns from investments in analytics and big data. The lack of a clear and good implementation plan is the root cause of this. It is not workable if a company decides to gather huge chunks of data and devise sound and worthy insights from the collected data. It is important to devise a comprehensive objective and questions for which it is necessary to analyze data and then strategize the results accordingly. The company needs to make sure that resources are not wasted at any rate, and that is why clear and comprehensive identification is required [60]. This challenge means that waste can be driven out of analytics and only valuable insights are obtained.

Third, companies that use data analytics formulate goals that are too high, posing a challenge to big data. They do not comprehend that the journey from data analytics to the optimization and 
improvement of business operations is a long one. The approach of the pilot project is one way to improvise, gain insight, and resultantly create fast wins. Taking one smart and small step makes the overall position of a company strong and stable. It will be a great challenge to determine the direction of movement that the organization follows in terms of data analysis implementation.

Fourth, the combination and integration of data are obstacles for financial companies. The creation of informed analysis for people in the field of finance has not been achieved. Without taking into consideration the format and location, the integration of various data sets needs to be made clear. Data analytics is a merger of both the IT and business operations. Accountants do not usually understand that, which is a threat to data analytics [59]. Usually, this problem takes place when there is an insufficient understanding of knowledge between finance and IT. A huge issue arises because there is a dissimilarity between the languages of IT and finance, which results in problems in the interpretation of the analysis. This often occurs because the departments are decentralized. A centralized system where the finance teams work with the departments of operations, the supply chain, and sales and marketing is required for better cooperation and a combination of data analytics.

When the integration of big data with the business occurs, many challenges arise. However, these issues - if addressed through proper pathways and strategies-can result in real value being gained for money generated from big data combination and analytics.

\subsection{Implications of Big Data in Finance}

\subsubsection{Implications of Big Data in Finance}

In the field of finance, big data has major implications. The processing of collected information is the basic requirement of the discipline of finance. The process of decision-making is mainly dependent on the information gathered from the raw data. The business information is considered an increment, taking into account the utility of big data in finance. Organized information is used by the company to proceed with the decision-making; otherwise, the raw and unprocessed data are worthless for the company. Various methods are adopted by the accountants to derive meaningful conclusions from the data. There are various advantages secured when using data analysis in various forms of time and cost reductions, impertinent decision-making, and new product development. The integration of data with high-power analytics provides ground for all tasks, relevant to the business to secure the best decisions.

In the field of finance, evolving big data has been integrated with corporate data. This helps to connect unstructured data sources with enterprise resource planning (ERP) systems. The conventional practices of traditional auditing and finance approaches need to be revolutionized using big data in large organizations. Audit analysis has also evolved through the integration of big data. Consequently, this has affected the behavioral research and judgments employed for audit [61]. Even though there are key opportunities associated with the integration of big data, there are some challenges that have been introduced for accountants.

\subsubsection{Implications of Big Data in Financial Markets}

For various activities along with operations, financial markets are always looking for reorganization, particularly considering the innovations in technology that are welcomed and accepted with significant optimism on financial markets and with significant impacts. Sun, Shi [2] states that the effectiveness of financial markets can be accredited to the quantity of the information and the process by which it is diffused. Therefore, the role of social media cannot be overlooked in financial markets. It can be considered one of the most dominant forces acting upon financial markets. A vast amount of information is generated every single day, varying from thousands to millions of pieces, by social media daily on a global level [62]. In financial markets, there are many indicators determined by big data, such as the following: The forecasting of net return; forecasting of the volatility; valuations of securities and the overall market; the increase in trading volumes; analyses of risk, management; 
valuations of portfolios; calculus of the performance of stock indices; calculus and the identification of movement and option pricing; measurement of the idiosyncratic volatility; and automated trading.

Shen and Chen [6] draw attention to the intermediate influence that financial markets have on big data. There are two components of this influence: The influence on the effective market hypothesis, and the influence on the market's dynamics. Considering the effective market hypothesis, it describes the number of times a name of an equity security is cited, the sentiment obtained from the content, and how frequently different keywords are searched for. A prominent example of this concept is Yahoo Finance. Conversely, the influence of financial big data is dependent on several theories of finance. Butler and Hansen [63] fixate on the factor, as it also aids in the analysis of sentiments in financial markets, which is represented by big datasets with machine learning methods.

\subsubsection{Implications of Big Data in Internet Finance}

The scientific breakthroughs have resulted in a revolutionary change in the way financial services are offered, especially by banks and FinTech enterprises. We can categorize the big data as a modern improvement to financial access considering the effect that big data has on the financial sector. Online transactions, banking applications, and internet banking result in the creation of a huge database of millions of parts of data daily. Hence, it is important to manage these data [64]. It cannot be overlooked that the management of internet financial services has a huge impact on security markets [65]. Zhang, Xiong [54], and Xie, Zou [66] bring our attention to the large volumes of data, innovations in services, safeguarding of information, and predictive correctness, to represent the relevance of the information technologies with finance. Big data solves the issue of information asymmetry and thus refines the effectiveness of mechanisms of pricing based upon risk and the management of risk. It is also useful in the collection and verification of data estimations of the credit risk status and fraud detection [67,68]. Jin, Wang [69] Nassirtoussi, Aghabozorgi [70], and Hajizadeh, Ardakani [71] show that technology for the mining of big data has great implications in the management of risk and detection of fraud.

\subsubsection{Implication of Big Data in Managing Financial Services}

In every aspect of business, big data is an emerging issue. Particularly in the field of finance, it has impacts in terms of different facilities, such as financial management, the management of risk, analysis of the financial position, and data management for financial applications. Business models and action plans of financial companies, as well as management, are continuously being changed due to the existence of big data on a very large scale. Additionally, currently, it is considered a very entrancing area of study. Finance business models are rapidly being proposed by scientists and experts through the means of big data techniques, specifically, methods used to control risk, analysis of the financial market, the creation of modern sentiment indices for finance through social networking sites, and tools based on information in diverse inventive ways [25]. Sun, Shi [2] discuss the four $\mathrm{V}$ elements of big data, which are velocity, volume, veracity, and variety. Diverse challenges are put forward constituting these characteristics, such as challenges of management, analytics, finance, and their implications. The successful and effectual organization and management of the financial sector—searching novel business models and dealing with conventional financial matters-are a part of these challenges. Traditional financial issues can be classified as automated trading, analysis of risk involved in credit lending, sentiments, analysis of the financial position, regulation regarding financial activities, management of the risk, and so on [2].

Furthermore, it can be observed that equity loans have certain credit banking risks associated with them and they can be measured by big data methods. The databases of a company are expanded every day because of the millions of financial operations being led. Therefore, in a short period, the evaluation of credit status and risk measurement needs to be carried out in an automatic way to resolve these issues. The measurement of credit risks and management of financial databases are the main problems that are currently encountered by bankers. When the segmentation of different risk groups needs to be 
assessed in financial databases, big data methods are very useful for management. Big data solutions also help banks that need to confirm the regulatory and legal requirements that are associated with the risk involved in credit and reliability risk domains [25]. Efficient, quick, and unbiased estimators need to be provided through the means of large data, which need to be managed by the big data approach. If the evaluation of the credit risk is precise and exact, then financial institutions and companies can gain advantages from it. This paves the way for people to obtain access to credit loans and simultaneously reduces the credit risk that banks face [72].

\section{Conclusions, Limitations, and Future Research}

Our study allows important conclusions to be presented based on the results obtained from the analysis conducted in this research. In this section, we present several important conclusions, also showing areas where further research may result in academic advances, by exploring aspects that were not possible to develop through our present study.

It is interesting to see that companies have begun to consider big data analysis as a very important area to develop. In particular, bigger companies have begun to frequently use big data techniques, namely in finance; however, the literature review shows that big data is not used enough in finance, mainly in smaller companies.

Financial services can be classified as a vast sector. In this sector, various problems are being dealt with in terms of a variety of features and attributes. The dependence of this sector on modeling tools has increased over time and the intensification of sophistication, relevant to analysis, has improved greatly. Financial services have evolved in an area that works for the betterment and development of the new analytical advances, as well as a field where the current quantitative methodologies from various separate fields can be used and tested in practice. As a conclusion, after the discussion on our analysis, we can say that the big data method is only particularly useful when it is used with the right set of minds. How the company is going to enhance the performance is primarily dependent on the way the company and its analysts use this important opportunity. With the usage of automated methods and the right reforms being taken at the right time, along with the integration of big data analysis, the revenue of the company can be increased significantly [73].

The finance field is moving towards digitization using big data. Digital revolution strengthens the level of the firm's performance, and the meeting of customer demands is being implemented in large corporations using these technologies. Most of the corporations are keeping the latest and critical data, and the consequence and impact of this accumulated information in the finance industry rises as a major query. In retrospect, financial services are digitally creative and treat data as the key component of the organization. Hence, we can conclude from the outcome of this study that the finance sector has been revolutionized by the use of big data, most importantly from the change in trade and investment due to real-time stock market insight, the detection and prevention of fraud, and the use of machine learning algorithms for more accurate risk analysis. Services offered via big data analytics are changing and improving customer satisfaction, providing an increase in revenues, allowing the turnaround time in manual processes to be reduced, ensuring reliable processing by the system, enhancing the path to purchase, analyzing the organization's financial performance, and improving and controlling the organization's product and growth. Even though big data has revolutionized the service industry, there are severe concerns about big data in the field of finance.

Our research clearly shows the existence of strong opportunities for organizations. The use of big data and the use of techniques to analyze it create strong competitive advantages for the companies that are able to do that. In a world of millions of new pieces of information, it is necessary to have a fast capacity for treating and analyzing it. This fast response gives the company a significant advantage to react and be pro-active. The analyzed publications show that there is a crescent use of big data and an evident recognition of the merit of analyzing it. Even if there are only smaller data sets, big data techniques can also be applied to allow additional gains and insights. 
Additionally, companies have to deal with new realities. Significant challenges arise and companies are now living the possibility of using strategies that come from big data.

Big data allows many new possibilities and has many implications. Organizations now have enormous possibilities that allow a set of recommendations to be developed. Evidently, companies can now use big data techniques to reach better and new kinds of results.

There are several measures that companies can follow. In this new world of fast running information and millions of pieces of information that are made available each day, companies have to be fast in collecting, treating, and processing the information. Moreover, they have to make it available for the respective departments as soon as possible, in a practical way that can easily support agents in the decision-making processes. The use of mathematical techniques, the use of the information that researchers make available, and the use of any other means of collected information may support companies in being proactive in the market and competitive.

As with any research, our study has some limitations, which are important to highlight. We begin by presenting a limitation concerning the sampling, as it did not capture conferences' publications. Recent technological tools for the analysis of big data were not used, which could have generated additional information for the study. ABS/ABDC ranking can also be used, but we did not use it for the data analysis. The number of published articles in this research is limited and future research may generate additional results by considering more studies in this area.

There is a set of major challenges in the world of finance that are generated by big data. All financial products concerning services are dependent on data and, in turn, also produce data. There have been many types of research conducted in this field, but there are still many areas within this field that need particular research developments. The discussion of our study gives a direction for future research. In fact, there is a need for further research in financial data management systems to address the technological challenges and the promising benefits of big data. Most importantly, further research is required to analyze how efficiently the large data sets can be handled and analyzed by researchers and analysts to devise more effective solutions. A bigger industry has big data that requires more effort and attention. Hence, it is more important to research and focus on larger industries' databases and on the techniques employed to manage them, compared to the databases of smaller firms and industries. The management of such large databases is usually very expensive, with it being very difficult to assess the desired data from among such large databases.

Another major area requiring further research is the data security in financial services. In addition to this, financial institutions need to introduce formal and cohesive strategies and processes to introduce and implement big data within their organizations. Furthermore, continual research on the influences of big data on security markets, especially on stock markets, should be emphasized. Finally, the problems related to big data in the field of finance investigated in the present research should be empirically verified by new research in the future.

Author Contributions: All the authors contributed to conceptualization, formal analysis, investigation, methodology, writing — original draft, and writing - review and editing. All authors have read and agreed to the published version of the manuscript.

Funding: This research received no external funding.

Conflicts of Interest: The authors declare no conflict of interest.

\section{References}

1. Andriosopoulos, D.; Doumpos, M.; Pardalos, P.M.; Zopounidis, C. Computational approaches and data analytics in financial services: A literature review. J. Oper. Res. Soc. 2019, 70, 1581-1599. [CrossRef]

2. Sun, Y.; Shi, Y.; Zhang, Z. Finance Big Data: Management, Analysis, and Applications; Taylor \& Francis: Oxfordshire, UK, 2019.

3. Routledge, B.R. Comments on: Big data in finance and the growth of large firms, by Juliane Begenau \& Maryam Farboodi \& Laura Veldkamp. J. Monet. Econ. 2018, 97, 88-90. 
4. Morshadul, H.M.; József, P.; Judit, O. Current landscape and influence of big data on finance. J. Big Data 2020, 7, 1-17.

5. Hale, G.; Lopez, J.A. Monitoring banking system connectedness with big data. J. Econom. 2019, 212, 203-220. [CrossRef]

6. Shen, D.; Chen, S.-H. Big data finance and financial markets. In Big Data in Computational Social Science and Humanities; Springer: Berlin/Heidelberg, Germany, 2018; pp. 235-248.

7. Ewen, J. How big data is changing the finance industry. Tamoco, 4 March 2019.

8. Hill, C. Where big data is taking the financial industry: Trends in 2018. Big Data Made Simple, 25 October 2018.

9. Razin, E. Big buzz about big data: 5 ways big data is changing finance. Forbes, 3 December 2015.

10. Diebold, F.X.; Ghysels, E.; Mykland, P.; Zhang, L. Big Data in Dynamic Predictive Econometric Modeling; Elsevier: Amsterdam, The Netherlands, 2019.

11. Einav, L.; Levin, J. The data revolution and economic analysis. Innov. Policy Econ. 2014, 14, 1-24. [CrossRef]

12. Mishra, D.; Gunasekaran, A.; Papadopoulos, T.; Childe, S.J. Big data and supply chain management: A review and bibliometric analysis. Ann. Oper. Res. 2018, 270, 313-336. [CrossRef]

13. Russom, P. Managing Big Data; TDWI Best Practices Report; TDWI Research: Seattle, WA, USA, 2013; pp. 1-40.

14. Prescott, M.E. Big Data and Competitive Advantage at Nielsen; Management Decision: Bingley, UK, 2014.

15. Stahl, F.; Schomm, F.; Vossen, G.; Vomfell, L. A classification framework for data marketplaces. Vietnam J. Comput. Sci. 2016, 3, 137-143. [CrossRef]

16. Kambatla, K.; Kollias, G.; Kumar, V.; Grama, A. Trends in big data analytics. J. Parallel Distrib. Comput. 2014, 74, 2561-2573. [CrossRef]

17. Wamba, S.F.; Akter, S.; Edwards, A.; Chopin, G.; Gnanzou, D. How 'big data' can make big impact: Findings from a systematic review and a longitudinal case study. Int. J. Prod. Econ. 2015, 165, 234-246. [CrossRef]

18. Dumbill, E. Planning for Big Data; Sebastopol: Sonoma County, CA, USA, 2012.

19. Hasan, S.; Shamsuddin, S.M.; Lopes, N. Machine learning big data framework and analytics for big data problems. Int. J. Adv. Soft. Compu. Appl. 2014, 6, 2-14.

20. Huang, Y.; Schuehle, J.; Porter, A.L.; Youtie, J. A systematic method to create search strategies for emerging technologies based on the web of science: Illustrated for 'Big Data'. Scientometrics 2015, 105, 2005-2022. [CrossRef]

21. Hashem, I.A.T.; Yaqoob, I.; Anuar, N.B.; Mokhtar, S.; Gani, A.; Khan, S.U. The rise of "big data" on cloud computing: Review and open research issues. Inf. Syst. 2015, 47, 98-115. [CrossRef]

22. De Mauro, A.; Greco, M.; Grimaldi, M. What is big data? A consensual definition and a review of key research topics. In AIP Conference Proceedings; American Institute of Physics: College Park, MA, USA, 2015; Volume 1644, pp. 97-104.

23. Waller, M.A.; Fawcett, S.E. Data science, predictive analytics, and big data: A revolution that will transform supply chain design and management. J. Bus. Logist. 2013, 34, 77-84. [CrossRef]

24. Marx, V. Biology: The big challenges of big data. Nature 2013, 498, 255-260. [CrossRef] [PubMed]

25. Chen, H.; Chiang, R.H.; Storey, V.C. Business intelligence and analytics: From big data to big impact. MIS Q. 2012, 36, 1165-1188. [CrossRef]

26. Tole, A.A. Big data challenges. Database Syst. J. 2013, 4, 31-40.

27. Rabhi, L.; Falih, N.; Afraites, A.; Bouikhalene, B. Big data approach and its applications in various fields. Procedia Comput. Sci. 2019, 155, 599-605. [CrossRef]

28. Blackburn, M.; Alexander, J.; Legan, J.D.; Klabjan, D. Big Data and the Future of R\&D Management: The rise of big data and big data analytics will have significant implications for R\&D and innovation management in the next decade. Res. Technol. Manag. 2017, 60, 43-51.

29. Grover, P.; Kar, A.K. Big data analytics: A review on theoretical contributions and tools used in literature. Glob. J. Flex. Syst. Manag. 2017, 18, 203-229. [CrossRef]

30. Ji, W.; Yin, S.; Wang, L. A big data analytics based machining optimisation approach. J. Intell. Manuf. 2019, 30, 1483-1495. [CrossRef]

31. Arunkumar, G.; Sabnis, A.; Vachhani, L. Robust steering control for autonomous homing and its application in visual homing under practical conditions. J. Intell. Robot. Syst. 2018, 89, 403-419. [CrossRef]

32. Holland, C.P.; Thornton, S.C.; Naudé, P. B2B analytics in the airline market: Harnessing the power of consumer big data. Ind. Mark. Manag. 2020, 86, 52-64. [CrossRef] 
33. Liu, Y.; Soroka, A.; Han, L.; Jian, J.; Tang, M. Cloud-based big data analytics for customer insight-driven design innovation in SMEs. Int. J. Inf. Manag. 2020, 51, 102034. [CrossRef]

34. Huang, L.; Wu, C.; Wang, B. Challenges, opportunities and paradigm of applying big data to production safety management: From a theoretical perspective. J. Clean. Prod. 2019, 231, 592-599. [CrossRef]

35. Belhadi, A.; Zkik, K.; Cherrafi, A.; Sha'ri, M.Y. Understanding big data analytics for manufacturing processes: Insights from literature review and multiple case studies. Comput. Ind. Eng. 2019, 137, 106099. [CrossRef]

36. Dubey, R.; Gunasekaran, A.; Childe, S.J.; Bryde, D.J.; Giannakis, M.; Foropon, C.; Roubaud, D.; Hazen, B.T. Big data analytics and artificial intelligence pathway to operational performance under the effects of entrepreneurial orientation and environmental dynamism: A study of manufacturing organisations. Int. J. Prod. Econ. 2020, 226, 107599. [CrossRef]

37. Shamim, S.; Zeng, J.; Choksy, U.S.; Shariq, S.M. Connecting big data management capabilities with employee ambidexterity in Chinese multinational enterprises through the mediation of big data value creation at the employee level. Int. Bus. Rev. 2019, 101604, 30. [CrossRef]

38. Aragona, B.; De Rosa, R. Big data in policy making. Math. Popul. Stud. 2019, 26, 107-113. [CrossRef]

39. Bag, S.; Wood, L.C.; Xu, L.; Dhamija, P.; Kayikci, Y. Big data analytics as an operational excellence approach to enhance sustainable supply chain performance. Resour. Conserv. Recycl. 2020, 153, 104559. [CrossRef]

40. Duan, L.; Xiong, Y. Big data analytics and business analytics. J. Manag. Anal. 2015, 2, 1-21. [CrossRef]

41. Jiang, W.; Lee, P.; Anandarajan, A. The association between corporate governance and earnings quality: Further evidence using the GOV-Score. Adv. Account. 2008, 24, 191-201. [CrossRef]

42. Pappas, O.I.; Mikalef, P.; Giannakos, N.M.; Krogstie, J.; Lekakos, G. Big data and business analytics ecosystems: Paving the way towards digital transformation and sustainable societies. Inf. Syst. Bus. Manag. 2018, 16, 479-491. [CrossRef]

43. Thackeray, R.; Neiger, B.L.; Hanson, C.L.; McKenzie, J.F. Enhancing promotional strategies within social marketing programs: Use of Web 2.0 social media. Health Promot. Pract. 2008, 9, 338-343. [CrossRef] [PubMed]

44. Hallikainen, H.; Savimäki, E.; Laukkanen, T. Fostering B2B sales with customer big data analytics. Ind. Mark. Manag. 2020, 86, 90-98.

45. Cerchiello, P.; Giudici, P. Big data analysis for financial risk management. J. Big Data 2016, 3, 18. [CrossRef]

46. Hussain, K.; Prieto, E. Big data in the finance and insurance sectors. In New Horizons for a Data-Driven Economy; Springer: Cham, Switzerland, 2016; pp. 209-223.

47. Tang, Y.; Xiong, J.; Luo, Y.; Zhang, Y.-C. How do the global stock markets Influence one another? Evidence from finance big data and granger causality directed network. Int. J. Electron. Commer. 2019, 23, 85-109. [CrossRef]

48. Boar, A.; Bastida, R.; Marimon, F. A systematic literature review. Relationships between the sharing economy, sustainability and sustainable development goals. Sustainability 2020, 12, 6744. [CrossRef]

49. Mio, C.; Panfilo, S.; Blundo, B. Sustainable development goals and the strategic role of business: A systematic literature review. Bus. Strateg. Environ. 2020. [CrossRef]

50. Xu, M.; Chen, X.; Kou, G. A systematic review of blockchain. Financ. Innov. 2019, 5, 27. [CrossRef]

51. Begenau, J.; Farboodi, M.; Veldkamp, L. Big data in finance and the growth of large firms. J. Monet. Econ. 2018, 97, 71-87. [CrossRef]

52. Fanning, K.; Grant, R. Big data: Implications for financial managers. J. Corp. Account. Financ. 2013, 24, 23-30. [CrossRef]

53. Yang, D.; Chen, P.; Shi, F.; Wen, C. Internet finance: Its uncertain legal foundations and the role of big data in its development. Emerg. Mark. Financ. Trade 2018, 54, 721-732. [CrossRef]

54. Zhang, S.; Xiong, W.; Ni, W.; Li, X. Value of big data to finance: Observations on an internet credit Service Company in China. Financ. Innov. 2015, 1, 1-18. [CrossRef]

55. Richins, G.; Stapleton, A.; Stratopoulos, T.C.; Wong, C. Big data analytics: Opportunity or threat for the accounting profession? J. Inf. Syst. 2017, 31, 63-79. [CrossRef]

56. Boyd, D.; Crawford, K. Critical questions for big data: Provocations for a cultural, technological, and scholarly phenomenon. Inf. Commun. Soc. 2012, 15, 662-679. [CrossRef]

57. Davenport, T.H. How strategists use "big data" to support internal business decisions, discovery and production. Strategy Leadersh. 2014, 42, 45-50. [CrossRef]

58. Hannan, S.A. An overview on big data and hadoop. Int. J. Comput. Appl. 2016, 154, 29-35.

59. Warren, J.D., Jr.; Moffitt, K.C.; Byrnes, P. How big data will change accounting. Account. Horiz. 2015, 29, 397-407. [CrossRef] 
60. Vasarhelyi, M.A.; Kogan, A.; Tuttle, B.M. Big data in accounting: An overview. Account. Horiz. 2015, 29, 381-396. [CrossRef]

61. Du, H.; Roohani, S. Meeting challenges and expectations of continuous auditing in the context of independent audits of financial statements. Int. J. Audit. 2007, 11, 133-146. [CrossRef]

62. Bollen, J.; Mao, H.; Zeng, X. Twitter mood predicts the stock market. J. Comput. Sci. 2011, 2, 1-8. [CrossRef]

63. Butler, J.E.; Hansen, G.S. Network evolution, entrepreneurial success, and regional development. Entrep. Reg. Dev. 1991, 3, 1-16. [CrossRef]

64. Kh, R. How big data can play an essential role in fintech evolutionno title. Smart Dala Collective, 24 July 2018.

65. Niu, S. Prevention and supervision of internet financial risk in the context of big data. Revista de La Facultad de Ingeniería 2017, 32, 721-726.

66. Xie, P.; Zou, C.; Liu, H. The fundamentals of internet finance and its policy implications in China. China Econ. J. 2016, 9, 240-252. [CrossRef]

67. Gray, G.L.; Debreceny, R.S. A taxonomy to guide research on the application of data mining to fraud detection in financial statement audits. Int. J. Account. Inf. Syst. 2014, 15, 357-380. [CrossRef]

68. Ngai, E.W.; Hu, Y.; Wong, Y.H.; Chen, Y.; Sun, X. The application of data mining techniques in financial fraud detection: A classification framework and an academic review of literature. Decis. Support Syst. 2011, 50, 559-569. [CrossRef]

69. Jin, M.; Wang, Y.; Zeng, Y. Application of data mining technology in financial risk analysis. Wirel. Pers. Commun. 2018, 102, 3699-3713. [CrossRef]

70. Nassirtoussi, A.K.; Aghabozorgi, S.; Wah, T.Y.; Ngo, D.C.L. Text mining for market prediction: A systematic review. Expert Syst. Appl. 2014, 41, 7653-7670. [CrossRef]

71. Hajizadeh, E.; Ardakani, H.D.; Shahrabi, J. Application of data mining techniques in stock markets: A survey. J. Econ. Int. Financ. 2010, 2, 109-118.

72. Pérez-Martín, A.; Pérez-Torregrosa, A.; Vaca, M. Big Data techniques to measure credit banking risk in home equity loans. J. Bus. Res. 2018, 89, 448-454. [CrossRef]

73. Cockcroft, S.; Russell, M. Big data opportunities for accounting and finance practice and research. Aust. Account. Rev. 2018, 28, 323-333. [CrossRef] 